\title{
Evaluation of Cucumber (Cucumis sativus L.) Genotypes under Hill Zone of Karnataka, India
}

\author{
Anusha Bhagwat", V. Srinivasa, Sharavati Bhammanakati and A.S. Shubha \\ Department of Vegetable Science, College of Horticulture, Mudigere-577132, India \\ University of Agricultural and Horticultural Sciences, Shivamogga, Karnataka, India \\ *Corresponding author
}

\section{A B S T R A C T}

Keywords

Cucumber,

Genotype, Growth,

Flowering, Yield,

Performance

Article Info

Accepted:

06 August 2018

Available Online:

10 September 2018
A field investigation was carried out with thirty genotypes of cucumber to evaluate the performance of the genotypes for growth and yield characters under hill zone of Karnataka. The genotype Sirsi Local-2 exhibited superiority for vine length, number of primary branches per plant, days to first harvest of the fruit, per cent marketable fruits per vine and chlorophyll content. Minimum number of node to appear first female flower, highest number of fruits per vine (13.90) and maximum yield per vine were found in the cultivar Poinsette. Fruit yield per hectare was highest in Banglore Local followed by Poinsette and Sirsi Local- 2. Lowest was seen in Pondecherry-1.The best genotypes identified in present investigation based on mean performance were Banglore Local, Poinsette and Sirsi Local -2. These genotypes can be utilized further for crop improvement programme in cucumber. Variations among different genotypes of cucumber may be attributed to inherent genetic makeup of the genotype and influence of environmental conditions.

\section{Introduction}

Cucumber (Cucumis sativus L.) is one of the most popular vegetable belong to the family Cucurbitaceae, with a chromosome number $2 n=14$.

It is an ideal summer vegetable crop chiefly grown for its edible tender fruits. It provides cooling effect, prevents constipation, useful in jaundice and seeds have number of ayurvedic uses. Seeds contain oil, which is helpful for brain development and body smoothness. In spite of the extensive cultivation and consumption, there is no systematic research work has been carried out in this region in order to understand the genetic architecture and endeavor in an improvement programme. Many important features of cultivated crops are not associated with discrete Mendelian traits, but are of a continuous or quantitative nature. Yield and many factors that affect it are subject to considerable environmental influence.

Hence, the present study was undertaken to estimate the growth and flowering parameters contributing to the yield performance of thirty different genotypes of cucumber under hill zones of Karnataka. 


\section{Materials and Methods}

The present research study was carried out at Department of Vegetable science, College of Horticulture, Mudigere during 2017-18. The material used for research work consists of thirty cultivars of cucumber (Table 1) procured from $\mathrm{COH}$ Banglore, $\mathrm{KRCCH}$ Arabhavi and UAHS Shivmogga. The experiment was laid out in accordance with Randomized Complete Block Design (RCBD) comprising of thirty treatments and two replications. All the cultural practices were same for all the cultivars used. Observations on growth, flowering and yield parameters were recorded and subjected to statistical analysis.

\section{Results and Discussion}

Field emergence, ranged from 7 (Arbhavi Local -5, JMG-1 and Pusa Uday) to 12 days (Arbhavi Local -1 and Green Salad). The genotype Sirsi Local-2 exhibited superiority for vine length $(2.22 \mathrm{~m})$, number of primary branches per plant (6.81), days to first harvest of the fruit (36.48), per cent marketable fruits per vine $(85.43 \%)$ and chlorophyll content $(2.12 \mathrm{mg} / \mathrm{g})$. Inter nodal length $(13.30 \mathrm{~cm})$ and rind thickness $(9.70 \mathrm{~mm})$ was maximum in Hasan Local whereas they were found minimum in US-646. Number of nodes per vine (21.34) was maximum in the genotype JMG-1and found least in Kerala -2 (10.85). Genotype TUPE recorded appearance of first male flower at the earliest node. Minimum number of days to appearance of first male, female, 50 per cent flowering was recorded by the genotypes US-646 (20.66), JMG-1 (26.13) and Arbhavi Local-5 (30.67), respectively. Minimum number of node to appear first female flower (3.51), minimum number of days to last harvest of the fruits (83.38), highest number of fruits per vine (13.90) and maximum yield per vine were found in the cultivar Poinsette. Banglore Local showed maximum fruit diameter of $6.18 \mathrm{~cm}$ and lowest was seen in IIHR-285 $(3.21 \mathrm{~cm})$.

Table.1 List of cucumber genotypes used in study

\begin{tabular}{|c|l|r|l|}
\hline SI. No & Genotypes & SI. No & Genotypes \\
\hline $\mathbf{1}$ & Arbhavi Local -1 & 16 & Honnavar Local \\
\hline $\mathbf{2}$ & Haveri Local & 17 & IIHR-285 \\
\hline $\mathbf{3}$ & Arbhavi Local-2 & 18 & IIHR-341 \\
\hline $\mathbf{4}$ & Arbhavi Local-3 & 19 & JMG-1 \\
\hline $\mathbf{5}$ & Poinsette & 20 & Phule Shubhangi \\
\hline $\mathbf{6}$ & Arbhavi Local-4 & 21 & Pebkernal \\
\hline $\mathbf{7}$ & Arbhavi Local-5 & 22 & Kerala-2 \\
\hline $\mathbf{8}$ & Banglore Local & 23 & NCU-1207 \\
\hline $\mathbf{9}$ & Davangere Local & 24 & Pondecherry -1 \\
\hline $\mathbf{1 0}$ & White Long & 25 & Pusa Uday \\
\hline $\mathbf{1 1}$ & Dharwad Local & 26 & Sirsi Local-1 \\
\hline $\mathbf{1 2}$ & EMU-102-402 & 27 & Sirsi Local-2 \\
\hline $\mathbf{1 3}$ & Green Salad & 28 & TUPE \\
\hline $\mathbf{1 4}$ & Hasan Loocal & 29 & US-640 \\
\hline $\mathbf{1 5}$ & Himangi & 30 & US-646 \\
\hline
\end{tabular}


Int.J.Curr.Microbiol.App.Sci (2018) 7(9): 837-842

Table.2 Per se performance of cucumber genotypes for growth and flowering parameters

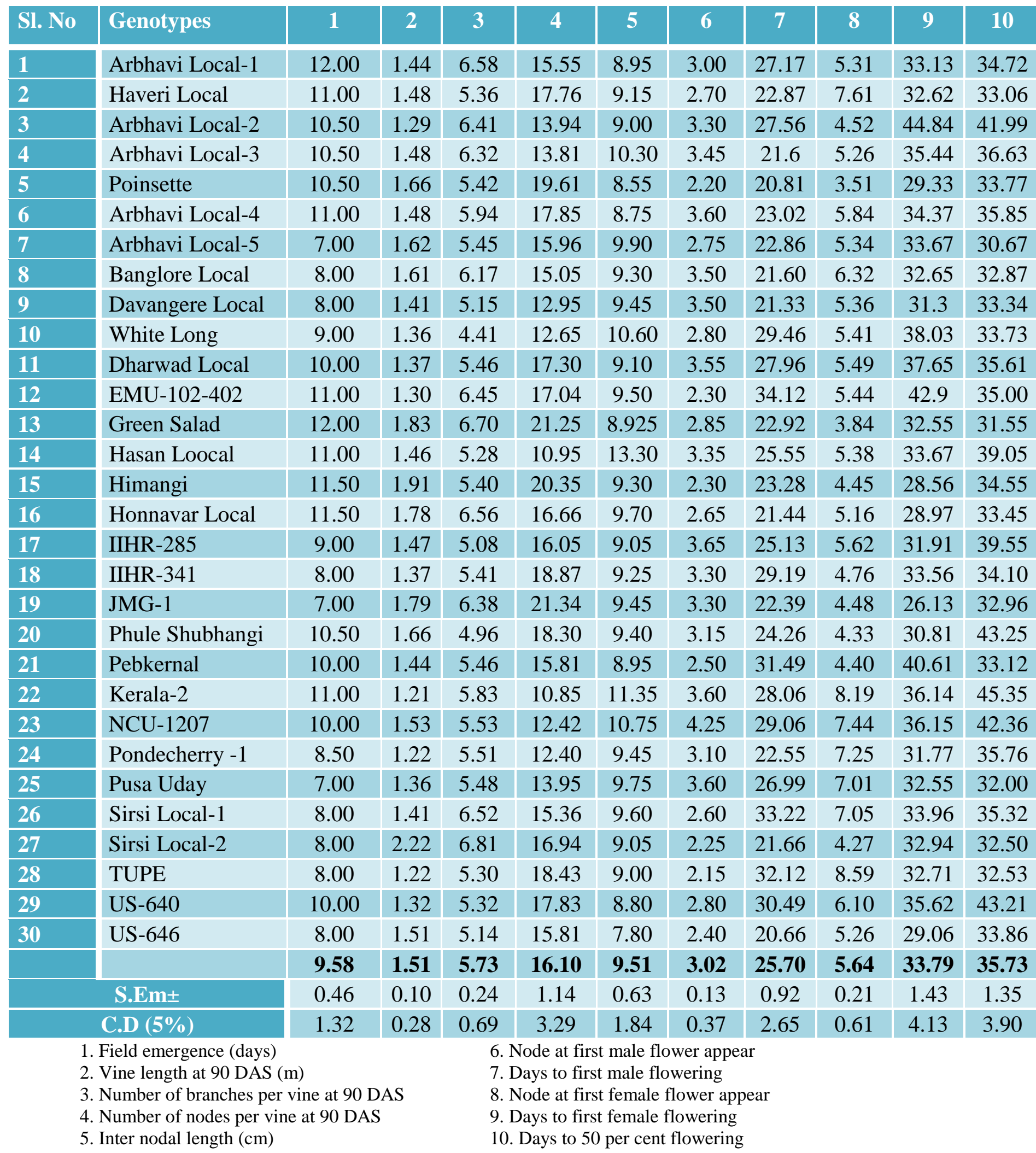


Table.3 Per se performance of cucumber genotypes for yield and quality parameters

\begin{tabular}{|c|c|c|c|c|c|c|c|c|c|c|c|c|c|c|}
\hline $\begin{array}{l}\text { SI. } \\
\text { No }\end{array}$ & Genotypes & 1 & 2 & 3 & 4 & 5 & 6 & 7 & 8 & 9 & 10 & 11 & 12 & 13 \\
\hline 1 & Arbhavi Local-1 & 41.77 & 85.46 & 5.50 & 4.09 & 17.10 & 14.17 & 132.01 & 73.31 & 26.69 & 0.73 & 8.11 & 0.96 & 6.76 \\
\hline 2 & Haveri Local & 39.28 & 88.44 & 7.15 & 5.11 & 15.82 & 19.84 & 172.51 & 75.55 & 24.45 & 1.23 & 12.35 & 0.60 & 6.01 \\
\hline 3 & Arbhavi Local-2 & 51.13 & 98.71 & 4.40 & 4.19 & 14.67 & 20.27 & 239.35 & 76.21 & 23.79 & 1.05 & 9.33 & 0.96 & 4.60 \\
\hline 4 & Arbhavi Local-3 & 44.21 & 89.34 & 5.90 & 4.47 & 18.22 & 20.08 & 177.85 & 76.82 & 23.18 & 1.05 & 9.33 & 1.24 & 4.75 \\
\hline 5 & Poinsette & 38.83 & 83.38 & 13.90 & 4.32 & 22.79 & 20.24 & 183.50 & 84.27 & 15.73 & 2.55 & 22.67 & 1.91 & 6.20 \\
\hline 6 & Arbhavi Local-4 & 49.56 & 83.78 & 6.30 & 3.49 & 13.72 & 20.34 & 198.48 & 67.87 & 32.13 & 1.25 & 11.11 & 1.37 & 5.45 \\
\hline 7 & Arbhavi Local-5 & 46.66 & 86.05 & 4.90 & 4.33 & 13.43 & 20.07 & 122.80 & 74.59 & 25.41 & 0.60 & 5.33 & 1.45 & 8.35 \\
\hline 8 & Banglore Local & 38.42 & 85.51 & 8.28 & 6.18 & 23.58 & 29.42 & 288.55 & 74.05 & 25.95 & 2.40 & 24.00 & 1.11 & 7.95 \\
\hline 9 & Davangere Local & 39.03 & 85.45 & 8.96 & 4.51 & 20.88 & 20.27 & 256.18 & 75.29 & 24.71 & 2.30 & 20.44 & 1.60 & 8.15 \\
\hline 10 & White Long & 46.88 & 93.87 & 4.04 & 5.36 & 23.63 & 29.66 & 160.54 & 64.72 & 35.29 & 0.65 & 5.78 & 1.39 & 8.95 \\
\hline 11 & Dharwad Local & 44.51 & 84.14 & 7.43 & 4.17 & 16.00 & 19.88 & 160.71 & 74.42 & 25.58 & 1.20 & 10.66 & 1.26 & 9.05 \\
\hline 12 & EMU-102-402 & 39.71 & 85.12 & 6.26 & 4.31 & 17.01 & 19.28 & 95.89 & 71.95 & 28.05 & 0.60 & 5.33 & 1.61 & 8.00 \\
\hline 13 & Green Salad & 39.07 & 85.27 & 9.96 & 5.18 & 23.82 & 20.50 & 210.63 & 82.76 & 17.24 & 2.10 & 21.00 & 0.67 & 8.45 \\
\hline 14 & Hasan Loocal & 47.68 & 95.56 & 8.75 & 5.31 & 23.78 & 19.93 & 120.42 & 74.83 & 25.17 & 1.05 & 9.32 & 0.64 & 9.70 \\
\hline 15 & Himangi & 37.94 & 112.34 & 9.57 & 5.25 & 15.54 & 19.91 & 255.91 & 81.72 & 18.28 & 2.45 & 21.78 & 1.11 & 6.55 \\
\hline 16 & Honnavar Local & 38.87 & 103.24 & 9.75 & 5.46 & 23.66 & 20.03 & 256.99 & 81.90 & 18.10 & 2.50 & 22.27 & 1.06 & 6.95 \\
\hline 17 & IIHR-285 & 46.17 & 94.65 & 6.70 & 3.21 & 13.43 & 13.49 & 156.05 & 75.39 & 24.61 & 1.05 & 9.33 & 1.25 & 6.10 \\
\hline 18 & IIHR-341 & 40.12 & 91.01 & 5.16 & 4.05 & 20.61 & 19.32 & 126.20 & 72.15 & 27.85 & 0.65 & 5.78 & 1.60 & 6.20 \\
\hline 19 & JMG-1 & 42.28 & 107.46 & 9.61 & 4.49 & 19.38 & 19.88 & 208.22 & 82.09 & 17.91 & 2.00 & 17.77 & 1.79 & 5.85 \\
\hline 20 & Phule Shubhangi & 52.01 & 106.29 & 9.21 & 3.82 & 12.27 & 17.92 & 119.23 & 78.09 & 21.91 & 1.10 & 11.00 & 0.79 & 8.05 \\
\hline 21 & Pebkernal & 39.27 & 96.17 & 9.09 & 3.56 & 16.98 & 12.16 & 242.19 & 76.63 & 23.37 & 2.20 & 19.55 & 1.24 & 8.40 \\
\hline 22 & Kerala-2 & 57.31 & 94.20 & 6.35 & 3.56 & 12.59 & 11.99 & 110.56 & 69.29 & 30.71 & 0.70 & 6.22 & 0.96 & 8.65 \\
\hline 23 & NCU-1207 & 45.11 & 84.89 & 5.60 & 3.39 & 14.99 & 16.28 & 151.92 & 66.24 & 33.76 & 0.85 & 7.56 & 0.96 & 8.65 \\
\hline 24 & Pondecherry -1 & 46.11 & 94.62 & 5.30 & 4.33 & 14.89 & 19.99 & 105.66 & 75.20 & 24.80 & 0.55 & 4.89 & 0.64 & 8.10 \\
\hline 25 & Pusa Uday & 40.66 & 84.05 & 9.10 & 5.33 & 16.78 & 27.63 & 148.69 & 81.21 & 18.79 & 1.35 & 13.50 & 0.74 & 8.55 \\
\hline 26 & Sirsi Local-1 & 41.67 & 93.12 & 7.05 & 5.56 & 24.59 & 28.55 & 341.70 & 75.08 & 24.92 & 2.41 & 18.74 & 0.66 & 8.45 \\
\hline 27 & Sirsi Local-2 & 36.48 & 107.00 & 10.75 & 5.17 & 21.13 & 29.63 & 236.80 & 85.43 & 14.57 & 2.55 & 22.63 & 2.11 & 7.75 \\
\hline 28 & TUPE & 38.58 & 85.97 & 5.54 & 4.41 & 18.28 & 19.82 & 145.03 & 74.49 & 25.51 & 0.80 & 7.11 & 1.87 & 6.50 \\
\hline 29 & US-640 & 51.81 & 84.77 & 9.01 & 4.35 & 15.87 & 19.33 & 171.79 & 75.77 & 24.23 & 1.55 & 13.78 & 1.83 & 5.25 \\
\hline 30 & US-646 & 52.51 & 90.49 & 7.75 & 4.37 & 17.99 & 19.87 & 129.68 & 76.18 & 23.82 & 1.00 & 8.89 & 1.26 & 4.40 \\
\hline & Mean & 43.79 & 92.01 & 7.58 & 4.51 & 18.12 & 20.33 & 180.87 & 75.79 & 24.21 & 1.42 & 12.85 & 12.85 & 7.23 \\
\hline & S.Em \pm & 2.20 & 3.30 & 0.29 & 0.17 & 1.87 & 0.77 & 18.73 & 2.71 & 2.71 & 0.15 & 1.44 & 1.44 & 0.26 \\
\hline \multirow{2}{*}{\multicolumn{4}{|c|}{$\begin{array}{l}\text { 1. Days to first harvest of the fruit } \\
\text { 2. Days to last harvest of the fruit } \\
\text { 3. Total number of fruits per vine } \\
\text { 4. Fruit diameter }(\mathrm{cm})\end{array}$}} & 0.84 & 0.48 & 0.65 & 2.24 & 54.17 & 7.83 & 7.83 & 0.45 & 4.15 & 4.15 & 0.75 \\
\hline & & & & $\begin{array}{l}\text { 5. Fr } \\
\text { 6. Fl } \\
\text { 7. } \mathrm{A} \\
\text { 8. } \mathrm{Pe}\end{array}$ & $\begin{array}{l}\text { th (c } \\
\text { fknes } \\
\text { fruit } \\
\text { marke }\end{array}$ & uits pe & \multicolumn{7}{|c|}{ 9. Per cent unmarketable fruits per vine $\quad 13$. Rind thickness $(\mathrm{mm})$} & \\
\hline
\end{tabular}


Maximum fruit length $(24.59 \mathrm{~cm})$ and fruit weight (341.70 g) were found in Sirsi Local1whereas they were found least in Phule Shubhangi and EMU-102-402, respectively. Flesh thickness was high in White Long (29.66 mm) and was low in Kerala -2 (11.99 $\mathrm{mm})$. Fruit yield per hectare was highest in Banglore Local $(24.00 \mathrm{~kg})$ followed by Poinsette $(22.67 \mathrm{~kg})$ and Sirsi Local- 2 (22.63 $\mathrm{kg}$ ). Lowest was seen in Pondecherry-1 $(4.89 \mathrm{~kg})$ as represented in tables 2 and 3 . Variations among different genotypes of cucumber may be attributed to inherent genetic makeup of the genotype and influence of environmental conditions. The results were in the line with the findings of Munshi and Acharya (2005) and Suchitra and Haribabu (2006) for growth parameters in bottle gourd. Similar results for yield and yield attributes were recorded by Kumar et al., (2008), Mohd and Khan (2009), Hossain et al., (2010), Reddy et al., (2013) in musk melon, Basumatary et al., (2014) in spine gourd, Janaranjani and Kanthaswamy (2015) in bottle gourd, Khan et al., (2015), Ene et al., (2016), Chinatu et al., (2017), Pushpalata et al., (2017), Ahirwar and Singh (2018) and Tyagi et al., (2018) in bitter gourd.

In the present investigation, the results revealed that growth and yield traits were varied among the different genotypes of cucumber. The genotype Sirsi Local-2 exhibited superiority for vine length, number of primary branches per plant, days to first harvest of the fruit, per cent marketable fruits per vine and chlorophyll content.

Minimum number of node to appear first female flower, highest number of fruits per vine (13.90) and maximum yield per vine were found in the cultivar Poinsette. Genotype Banglore Local recorded highest value for fruit diameter and frit yield per hectare. Thus from the study, considering the better performance for growth and yield parameters Banglore Local, Sirsi Local -2 and Poinsett genotypes were better for cultivation under hill zone of Karnataka.

\section{References}

Ahirwar, C.S and Singh, D. K., 2018. Assessment of genetic variability in cucumber (Cucumis sativus L.) Int. J. Curr. Microbiol. App. Sci., 7(3): 813822

Basumatary, P., Bora, G. C., Kalita, U. C., Saikia, L and Deka, N.C., 2014. Variability and correlation studies in spine gourd (Momordica dioica Roxb.). Direct Res. J. Agric. Food Sci. 2(7): 7781

Chinatu, L. N., Onwuchekwa-henry, C. B and Okoronkwo, C. M., 2017. Assessment of yield and yield components of cucumber (Cucumis sativus L.) in Southeastern Nigeria. Int. J. Agric. Earth Sci., 3:35-44.

Ene, C.O., Ogbonna, P. E., Agbo, C.U and Chukwudi, U.P., 2016. Studies of phenotypic and genotypic variation in sixteen cucumber genotypes. Chilean $J$. Agric. Res., 76:307-313.

Hossain, M. F., Rabbani, M.G., Hakim, M. A., Amanullah, A. S. M., Ahsanullah, A. S. M., 2010, Studies on variability, character association and yield performance of cucumber (Cucumis sativus L.). Bangladesh. Res. Public J., 4:297-311

Janaranjani, K. G and Kanthaswamy, V., 2015, Correlation studied and path analysis in bottle gourd [Lagenaria siceraria (Molina) Standl.], J. Horti., 2: 1

Khan, Z., Shah, A. H., Gul, R., Mazid, A., Khan, U and Ahmad, H., 2015, Morpho-agronomic characterization of cucumber germplasm for yield and yield associated traits. Int. J. Agronomy Agric. Res., 6:1-6. 
Kumar, A., Kumar, S and Pal, A. K., 2008, Genetic variability and characters association for fruit yield and yield traits in cucumber. Indian J. Hort., 65:423-428.

Mohd, M and Khan, F. A. S., 2009, Variability and character association analysis in cucumber germplasm. Agric. Biol. Res., 25:87-91.

Munshi, R and Acharya, P., 2005, Varietal evaluation in bottle gourd genotypes. Ind. Agric. 49(3/4): 213-221.

Pushpalatha, N., Anjanappa, $\mathrm{M}$ and Pitchaimuthu, M., 2017, Genetic variability and heritability for growth and yield of cucumber (Cucumis sativus L.). Green farming. 8: 6-10.
Reddy, B. P. K., Begum, H., Sunil, N., Reddy, M. T., Babu, J. D and Reddy, R. S. K., 2013, Correlation and path coefficient analysis in muskmelon (Cucumis melo L.). Suranaree J. Sci. Tech. 20(2):135-149.

Suchitra, V and Haribabu, K., 2006, Correlation studies and path coefficient analysis in bottle gourd [Lagenaria siceraria (Mol.) Stand L.]. The Allahabad Farmer, 111(1): 67-73.

Tyagi, N., Singh, V. B and Praveen kumar maurya. 2018, Studies on genetic variability, heritability and genetic advance in bitter Gourd (Momordica charantia L.) for yield and yield contributing traits. Int. J. Curr. Microbiol. App. Sci., 7(3): 1788-1794

\section{How to cite this article:}

Anusha Bhagwat, V. Srinivasa, Sharavati Bhammanakati and Shubha, A.S. 2018. Evaluation of Cucumber (Cucumis sativus L.) Genotypes under Hill Zone of Karnataka, India. Int.J.Curr.Microbiol.App.Sci. 7(09): 837-842. doi: https://doi.org/10.20546/ijcmas.2018.709.100 